\title{
Mezzanine financing for hospitality property owners
}

Received: 4 August 2003

\author{
Adam F. Weissenberg \\ is a partner in the Deloitte \& Touche LLP's Tri-State Hospitality and Real Estate Services \\ Group and the East Sector Director of the National Hospitality Practice. He specialises \\ in providing business advisory services such as due diligence, operational analysis, \\ vendor selections and internal control analysis for various segments of the hospitality \\ industry, including hotels, restaurants, ski resorts and food service companies.
}

\section{Jonathan Cohen}

has 17 years' experience in the real estate services industry. His work has included providing technical expertise to consulting engagements as well as identifying new business in the real estate capital markets industry. As a leader of the financial advisory services business line at Deloitte \& Touche, he has acted as adviser in a number of loan portfolio sales. He is also a leader of the due diligence service line and has performed load underwriting, portfolio acquisition or portfolio disposition due diligence services. He can be contacted on +1 2124366798 .

\section{Pete Culliney}

is the director of Deloitte \& Touche's National Center for Real Estate Research and Technology. He has been involved in the field of corporate research and business intelligence for over 12 years and works extensively in the development of thought pieces, publications and presentation materials for speaking engagements and conferences as well as working directly with client service teams. He can be contacted on +1 2124365039 .

\section{Abstract}

This paper intends to familiarise owners of hospitality properties with an additional financing tool available to them which recently has become very popular. Mezzanine financing is a source between the equity ownership and the overriding primary debt on the property. The availability of this financing tool has become increasingly important over the past couple of years since senior mortgage lenders have been very conservative in their underwriting guidelines. Accordingly, they have reduced the loan proceeds they are willing to lend. Unless the hospitality property owner is willing to put up a substantial amount of equity, which could be up to 40-45 per cent of the property's value, mezzanine financing is a possible solution. The paper also discusses which type of lenders are active in this arena and which characteristics hospitality property owners should focus on as they look to pursue a lender to fit their individual needs. Finally, the paper briefly sets forth the mezzanine financing structures.

\section{Keywords:}

debt, finance, hospitality, hotel, lending, mezzanine 


\section{OVERVIEW}

With a slumping economy and slashed travel budgets, leisure and business travellers have been staying home more than they have been on the road - to the dismay of hospitality property owners. According to the Summer 2003 Hotel Outlook report, ${ }^{1}$ annual occupancy rates have declined from approximately 68.0 per cent in the years 1998-2000 to 62.9 per cent in 2001 and 61.5 per cent in 2002. Additionally, revenue per available room, which is a key indicator of hotel profitability, has decreased from a peak of US\$69.13 in 2000 to US\$61.76 in 2001 and US\$58.55 in 2002.

To further compound the hotelier's dilemma - as their properties still need upkeep and rehabilitation — lenders have become all the more stringent in their lending and have forced loanto-value ratios (known as LTVs, and calculated as the loan balance divided by the property's value) way down and underwriting requirements way up. This rigorous enforcement of lending criteria is based on the fact that delinquency rates for loans collateralised by hospitality properties, either on the books of a portfolio lender or included in a lender's commercial mortgage-backed securitisation programme, are almost twice as high as for other property types. According to the American Council of Life Insurers, ${ }^{2}$ delinquency rates for hotel/motel properties almost doubled from 0.66 per cent as of 31 December 2002 to 1.29 per cent as of 31 March 2003.

\section{What is mezzanine finance?}

With underwriting guidelines becoming much more strict in the last two years, the answers to the pressing financial demands of a hospitality property owner looking for greater loan proceeds can be found in the mezzanine sector. One is not talking here about a great place on a mezzanine level to situate a bar or café overlooking the lobby, but rather a specific financing tool that comes into play between the equity ownership and the overriding primary debt on the property. Mezzanine finance is a middle ground that some will say works as the best of both worlds. Using a variety of structures, mezzanine finance allows a property owner to take additional monies out of a property above the maximum available from a senior mortgage lender due to the strict LTV requirements. Where standard LTVs for senior debt on hospitality properties are typically in the 50 per cent range, the addition of a mezzanine loan can net the borrower additional proceeds up to an additional 20-25 per cent of the property's value. This extra level of financing carries additional risk for lenders, and is usually paid for through loan programmes that have higher interest rates and possible equity or cash flow components. With record low rates in today's market, however, the blended interest rate of the senior loan and the mezzanine loan (typically in the low to high teens) is still attractive to the borrower.

Many of the largest hotel chains, including Starwood, Marriott and Cendant, have built-in programmes to bring this type of loan option to their property owners as an incentive for longer management contracts or franchise agreements. Even in these down 


\section{Appeal of mezzanine financing}

times, hotel properties must remain competitive, and to do this they must continue to offer the services and amenities their clients demand. Mezzanine finance at this time provides many operators with the opportunity to upgrade and refurbish their properties in preparation for the next upswing in leisure and business travel.

In addition to property improvement, renovation or repositioning uses, mezzanine financing is also often found in places where it is intended to assist in propelling newly constructed hotels from the development phase to stabilised operations, or it is used to expand the facilities or add amenities at newly purchased properties as well as simply providing an extra bit of cash for purchase above the available mortgage amount.

So with mezzanine financing filling this important niche between skittish first-mortgage holders and hotel owners seeking more leverage from their properties, there is a vast range of bankers and private lenders who are looking for the extra reward that comes from squeezing into the mezzanine niche. This paper sets out the types of lender, the characteristics needed to select the right lender and how the lenders structure their deals in this turbulent sector.

\section{WHICH TYPE OF LENDER TO ACCESS}

When a hospitality company concludes that mezzanine financing best suits its needs, it must first choose which type of lender it wants to access. The different types of mezzanine lenders typically include commercial banks, investment banks, real estate opportunity funds and small speciality lenders, as well as other capital sources. This choice may become more limited for owners of hospitality properties, since the lodging industry has been perceived by many lenders as a high-risk business for the past two years. Even if mezzanine lenders participate in this market, they have increasingly stricter underwriting requirements. Thus the owner of a hospitality property may find that the most realistic chance of obtaining mezzanine financing is through a real estate opportunity fund specialising in higher-yielding debt financing or a smaller speciality lender who focuses primarily on the hospitality industry, even though there are numerous lending sources available. From a lender's perspective, the hospitality industry offers the highest returns in terms of interest rates charged, which has led to an abundance of lenders. Lenders are more cautious, however, due to the uncertainty of today's market.

\section{WHICH LENDER TO SELECT BASED ON THE PROPERTY OWNER'S NEEDS}

The next step for the hospitality property owner is researching which lender to select. The goal of the owner is to maximise proceeds at the lowest interest rate possible. Lenders will examine numerous characteristics of each prospective mezzanine financing, including the loan size, the type of hospitality property, the property location, the combined LTV ratio, including the first- 
Location and property type are key mortgage principal balance, and the type of mezzanine financing needed.

\section{Loan size}

Loan size is the expected proceeds that the mezzanine lender would be willing to lend as a result of its analysis of the above characteristics and its risk tolerance. Mezzanine lenders typically operate in loan size niches - the smaller lenders staying in a range of US\$1-5m, the mid-range lenders operating in a range between US $\$ 2-15 \mathrm{~m}$ and the larger investors targeting a range of US\$15m up to US\$200m. Mezzanine lenders may make exceptions to the loan size parameters in certain cases, but the universe of lenders available to the borrower contracts depending on the amount of capital needed by the borrower.

\section{Property type}

Property type is also a very important characteristic in assessing which mezzanine lender is the right fit for a borrower's needs. Many lenders favour certain property types, such as class A office or regional malls. But many lenders will avoid certain property types, such as assisted living or hospitality properties. Thus the universe of first-mortgage lenders as well as mezzanine lenders drastically shrinks for owners of hospitality properties seeking debt financing. The effect of this is that the mezzanine lenders that are lending on hospitality properties see a disproportionate amount of hospitality deals compared to core property types (office, retail, multi-family and industrial). Even if the mezzanine lender is active in lending in the hospitality sector, it may limit the loans it makes to certain types of properties (stabilised, full-service, luxury, resort, etc). Certain lenders will specialise in certain properties, typically in conjunction with the loan size. The lenders which are originating smaller loans will typically focus on the smaller limited-service properties, while the larger institutional lenders may focus on the larger full-service hotels, or lend at the corporate level to a chain or collection of hotels (many times in conjunction with a first mortgage).

\section{Property location}

The property location is another variable taken into account by mezzanine lenders. Certain mezzanine lenders will only lend in certain geographic regions, while others will lend in only top markets (New York City, Washington, DC, etc). Thus if a hospitality property owner has a limited-service hotel or a fullservice hotel in a lower-tiered market, it may find financing at very unattractive terms, if at all.

\section{Combined LTV ratio}

The key financial component of a lender's investment decision is the combined LTV. Since late 2001, first-mortgage lenders have been 


\section{Hospital properties are more risky}

very conservative in the underwriting of hospitality properties, often only lending up to 50 per cent of the value of the property, while the same lender probably would lend up to 70 to 75 per cent of the value of a core property type in the same market. Many mezzanine lenders participating in the hospitality sector will bridge some of the gap between the senior loan and the amount of equity the borrower is able to contribute, but they probably would not go beyond 70 to 75 per cent of the value. In comparison, mezzanine lenders may go as high as 85 to 90 per cent on core property types in the same market. Thus hospitality property owners should research the risk appetite of mezzanine lenders to determine which ones are likely to provide the most proceeds. In addition, borrowers should research the interest rate pricing based on the combined LTV ratio and other loan and property characteristics. Pricing is exponential as the LTV ratio goes up (ie the interest rate increase from a 75 to 80 per cent LTV is significantly greater than an increase in the LTV from 70 to 75 per cent).

\section{Mezzanine terms}

Mezzanine loans are typically much shorter than first mortgages and typically mature in the two-to-five-year time frame. This is an important consideration for the borrowers, as they need to assess their ability to refinance or pay off this loan in this time frame.

\section{Type of mezzanine financing}

Mezzanine lenders will also base their lending decision upon the current situation of the property. Based on the lender's risk tolerance, certain types of mezzanine lending may not be part of the institution's strategy. Key factors include whether the property is stabilised; whether the property is in need of major renovation or is in the process of being converted to an alternate use or repositioned; and if the financing is for new development.

- Stabilised properties. This category encompasses hospitality properties that currently have sufficient cash flow to cover the combined debt service of a first mortgage and a mezzanine loan and have strong operators.

- Renovation/repositioning/conversion to alternate use ('valueadded'). This category includes hospitality properties that have some existing cash flow, but possibly not enough to cover the combined debt service of a first mortgage and a mezzanine loan, as well as properties undergoing some sort of rehabilitation. This may be a property that is converting from one brand to another brand, adding certain amenities or just upgrading or renovating the existing rooms.

- New development. This category consists of to-be-built hospitality properties with no existing cash flow.

- Acquisition. This category includes acquisitions of single properties or multiple properties. 


\section{Determining structure}

\section{Mezzanine financing can help}

Typically, the majority of the lenders prefer to lend to stabilised properties or provide financing for renovation. Obtaining financing through a mezzanine lender may be much more difficult if obtained in connection with new development or acquisitions. As the risk is much higher for the lender, the underwriting criteria are much more stringent and the length of time to obtain the financing may increase, as may the amount of due diligence required by the lender.

\section{DEAL STRUCTURES}

The structure of the deal is usually predicated on the type of mezzanine financing. A borrower seeking mezzanine financing on a stabilised property probably will not agree to any type of payment to the lender other than interest only. The reason for this is threefold: first, the loan, provided the combined LTV does not exceed 85 per cent, is generally not as risky as the other types of mezzanine structures; secondly, there is a lot of competition in this part of the mezzanine sector and many mezzanine lenders are very aggressive on the pricing (ie lower interest rates and no participation in the property's cash flow or residual value); and thirdly, in many cases the senior loan on a stabilised property has been included in a commercial mortgage-backed securitisation, and as such the intercreditor agreement, typically a difficult document to negotiate between the senior lender and the mezzanine lender, is often standardised and reduces potential issues later on in the process.

Value-added and new development deals are typically more risky and there is not as big a universe of mezzanine lenders. Thus, mezzanine lenders often require participation in cash flow and in the residual value. In addition, the borrower is usually required to set up a lockbox, whereby all cash flow from the property after the payment of the senior loan is controlled by the mezzanine lender and distributed according to the mezzanine loan documents.

The risk of the mezzanine loan is directly related to the amount of cash flow the borrower receives. In value-added deals with high combined LTV ratios, the borrower typically receives little to no cash flow from the property until a refinancing of the loan or a sale of the property.

\section{SUMMARY}

In today's low-interest-rate environment mezzanine financing provides an attractive source of financing for borrowers to supplement first mortgages without supplying additional equity. But the borrower needs to spend time finding the best lender to meet their needs based on the use of the funds, the type of property, the location and repayment terms. There are ample numbers of lenders willing to consider making mezzanine loans to hospitality owners, but finding a lender with terms the borrower is willing to accept will take research and persistence. 


\section{References}

1. HRG/Torto Wheaton Hotel Outlook (2003) Torto Wheaton Research, Boston, MA, Summer.

2. Mortgage Loan Portfolio Profile (2003) American Council of Life Insurers, Washington, DC, 31 March. 